\title{
Factors influencing tropical Island freshwater fishes: species, status, threats and conservation in Hainan Island
}

\author{
Wen Xiong ${ }^{1, *}$, Qiang Wang ${ }^{2}$, Dong Xie ${ }^{3}$, David H Fletcher ${ }^{4}$ and Dekui He ${ }^{5,6, *}$ \\ ${ }^{1}$ College of Fisheries, Guangdong Ocean University, Zhanjiang 524088, PR China \\ 2 School of Ecological and Environmental Sciences, East China Normal University, Shanghai 200062, PR China \\ 3 Co-Innovation Center for Sustainable Forestry in Southern China, Nanjing Forestry University, Nanjing 210037, PR China \\ ${ }^{4}$ Department of Life and Environmental Sciences, Faculty of Science and Technology, Bournemouth University, Poole, BH 125 BB, UK \\ ${ }^{5}$ Laboratory of Biological Invasion and Adaptive Evolution, Institute of Hydrobiology, Chinese Academy of Sciences, Wuhan 430072, \\ PR China \\ ${ }^{6}$ Southeast Asia Biodiversity Research Institute, Chinese Academy of Sciences, Menglun, Mengla, Yunnan 666303, PR China
}

\begin{abstract}
Hainan Island is located within the Indo-Burma global biodiversity hotspot, however, the freshwater fish fauna on this island is poorly understood. Based on field investigations and literature review, we compiled a list of 154 freshwater fish species (138 native and 16 non-native) belonging to 10 orders, 31 families and 104 genera found on Hainan Island. Of these, 31 species are endemic to China. The native freshwater fish fauna in Hainan Island is affiliated to South China sub-region of the Oriental Region. Current knowledge suggests that overexploitation, water pollution, flow modification, habitat degradation, and non-native species have severely reduced the freshwater fish biodiversity in Hainan Island. To protect freshwater fish biodiversity and fisheries in Hainan Island, some new measures should be adopted and current measures better enforced. This study constitutes an important resource for conservation management of freshwater fishes in Hainan Island.
\end{abstract}

Keywords: Biodiversity / conservation / freshwater fish / tropical Island / species diversity

Résumé - Facteurs influençant les poissons d'eau douce des îles tropicales: espèces, situation, menaces et conservation dans l'île de Hainan. L'île de Hainan est située dans le point névralgique de la biodiversité mondiale de l'Indo-Birmanie, mais la faune piscicole d'eau douce de cette île est mal connue. D'après les investigations sur le terrain et l'analyse documentaire, nous avons compilé une liste de 154 espèces de poissons d'eau douce (138 espèces indigènes et 16 espèces non indigènes) appartenant à 10 ordres, 31 familles et 104 genres trouvés sur l'île de Hainan. Parmi elles, 31 espèces sont endémiques en Chine. La faune indigène des poissons d'eau douce de l'île de Hainan est affiliée à la sous-région de la Chine du Sud de la Région Orientale. Les connaissances actuelles suggèrent que la surexploitation, la pollution de l'eau, la modification des débits, la dégradation de l'habitat et les espèces non indigènes ont sérieusement réduit la biodiversité des poissons d'eau douce de l'île Hainan. Afin de protéger la biodiversité des poissons d'eau douce et les pêcheries de l'île de Hainan, de nouvelles mesures devraient être adoptées et les mesures actuelles mieux appliquées. Cette étude constitue une source importante pour la gestion de la conservation des poissons d'eau douce dans l'île de Hainan.

Mots-clés : Biodiversité / conservation / poissons d'eau douce / ile tropicale / diversité des espèces / diversité spécifique

\section{Introduction}

Freshwater ecosystems are considered to be some of the Earth's most important hotspots for biodiversity (Strayer and

\footnotetext{
*Corresponding authors: chinaxiongwen@gmail.com,

hedekui@ihb.ac.cn
}

Dudgeon, 2010). However, these ecosystems are also recognized as some of the most endangered on the planet (Gleick, 2003; Dudgeon et al., 2006), because the extinction risks are significantly greater than those in terrestrial and marine ecosystems (Ricciardi and Rasmussen, 1999; Abell, 2002). Especially, freshwater fish received widespread attention owing to its high diversity and endemism in the 
world (Olden et al., 2010). However, the researches about the conservation of freshwater fishes are very scarce (Strayer and Dudgeon, 2010).

China is one of the countries with the greatest freshwater fish diversity (Xing et al., 2016). However, most studies on Chinese freshwater fishes focus on fish diversity of only a few large rivers, for example the Yangtze River (Fu et al., 2003) and Mekong River (Kang et al., 2009). This bias, towards these larger rivers, is likely due to the presence of important research institutions in these regions, such as the Institute of Hydrobiology in Wuhan - centrally placed for the Yangtze River. Whilst the focus of attention and resources on these larger rivers undoubtedly contributes towards a far more complete understanding of their assemblages and functioning, it also means that some regions with high freshwater fish diversity are not studied sufficiently, for example, Hainan Island.

Hainan Island is the second largest Island of China, and is situated in the southernmost part of the country. It is also a biodiversity hotspot (Myers et al., 2000; Sodhi et al., 2001), as a great number of studies, focused on terrestrial plants (Zhang, 2001), birds (Chen, 2008), aquatic plants (Wang et al., 2008) and mammals (Chen, 2009) have shown. Whilst research has been conducted on the Southeastern distributional patterns of East Asian freshwater fish (Zakaria-Ismail, 1994; Yap, 2002), there is little information available specifically on the freshwater fishes Hainan Island.

The objectives of the present study were: (1) to compile an up-to-date inventory of the freshwater fish fauna of Hainan Island; (2) to review the main threats to freshwater fish biodiversity; and (3) to review recommendations for fish biodiversity conservation.

\section{Materials and methods}

\subsection{Study area}

Hainan Island is located in the northern part of the South China Sea $\left(18^{\circ} 10^{\prime}-20^{\circ} 10^{\prime} \mathrm{N}, 108^{\circ} 37^{\prime}-111^{\circ} 03^{\prime} \mathrm{E}\right)$, and is separated from Chinese mainland by the narrow Qiongzhou straits (Fig. 1). With an area of about $33900 \mathrm{~km}^{2}$, Hainan Island is the second largest Island in China, just after Taiwan Island. The land area of Hainan Island accounts for only $0.35 \%$ of China'sland area, but accounts for $42.5 \%$ of the total tropical land area of China (Pearl River Fisheries Research Institute, 1989).

Hainan Island is oval-shaped, with an approximately $45^{\circ}$ orientation and measures $260 \mathrm{~km}$ from northeast to southwest and $180 \mathrm{~km}$ from southeast to northwest. The Island has a staircase-like topographic structure, descending step by step from towering mountains to flat tablelands (mesas) and plains at its periphery. Mountains and hills account for $38.7 \%$ of area of the total land area, with the mountains mainly distributed in the southern part of the central island and the hills mainly located in the central and northwestern parts of the Island. The mesas and coastal terraces, surrounding the mountains and hills, account for approximately $49.5 \%$ of the land area of the Island. The island is surrounded by a coastal plain, which accounts for about $11.2 \%$ of the total land area. The elevation of most Hainan Island's mountains is between $500-800 \mathrm{~m}$, with only few mountains over $1500 \mathrm{~m}$. Wuzhishan Mountain is the highest mountain $(1876 \mathrm{~m})$ and is located at the center of the island. Yinggeling Mountain is the second highest mountain $(1811 \mathrm{~m})$ and is located northwest of Wuzhishan Mountain. Yajiadaling Mountain is the third highest mountain $(1519 \mathrm{~m})$ and is located in the west.

Rivers in Hainan Island mostly originate from the central mountainous area, forming a radiating river system. There are 154 rivers flowing into the sea. The Nandu River, Wanquan River, and Changhua River are the largest rivers in Hainan Island, the basin area of these three rivers accounts for about $47 \%$ of the area of Hainan Island (Zeng and Zeng, 1989).Most rivers in Hainan Island are characterized by a short course (less than $350 \mathrm{~km}$ ), high gradient, and fast flow. In wet season, the water levels of most rivers change rapidly. The wet season flood runoff accounts for over $80 \%$ of the total annual runoff. In dry season, some rivers dry out completely.

The coastline of Hainan Island is $1823 \mathrm{~km}$ in length and consists mainly of lagoons, harbors, mangroves, coral reefs, and estuaries. During 50 years of coastal development, the area of mangrove and coral reef have been reduced by $50 \%$ and $55.5 \%$, respectively, while the length of shore reef has decreased by $59.1 \%$ (Zou et al., 1999).

The climate of Hainan Island is tropical maritime and is dominated by monsoons, in April and October, with predominant northeasterly winds in winter (from November to March) and southwesterly winds in summer (from May to September). Annual average temperature varies geographically, from $22.8^{\circ} \mathrm{C}$ to $25.8^{\circ} \mathrm{C}\left(16-4{ }^{\circ} \mathrm{C}\right.$ in January and $28-9{ }^{\circ} \mathrm{C}$ in August).The annual average precipitation is from $961 \mathrm{~mm}$ to $2439 \mathrm{~mm}$, mainly concentrated from May to October, when the southwesterly winds dominate.

\subsection{Sources of information}

Both field investigations and literature review were used for collecting data of freshwater fish species in Hainan Island. Over ten ichthyological surveys were conducted on Hainan Island in different seasons between 2000 and 2016. We searched for literature that contained the following combination of words: "Hainan" and "freshwater fish" or "freshwater ichthyo" in the title, abstract, or keywords from the Thomson institute for scientific information (ISI, http://www.isiknowledge.com) and CNKI (http://www.cnki.net). We also collected information from some Chinese books, such as The Freshwater and Estuaries Fishes of Hainan Island (Pearl River Fisheries Research Institute, 1989). Based on our investigations and literature review, we compiled a preliminary list of the fish species of Hainan Island. To avoid confusion caused by synonyms and changes of common names, we identified the valid Latin names of every species in Catalog of Fishes database (https://www.calacademy.org/scientists/projects/catalog-of-fishes), which covers more than 61700 fish species and subspecies with authoritative references. The present study compiled a preliminary inventory of freshwater fishes for Hainan Island (Tab. 1).

\section{Fish biodiversity and conservation}

There have been over 1300 freshwater fish species listed in China (Xing et al., 2016). The present study revealed that a total 


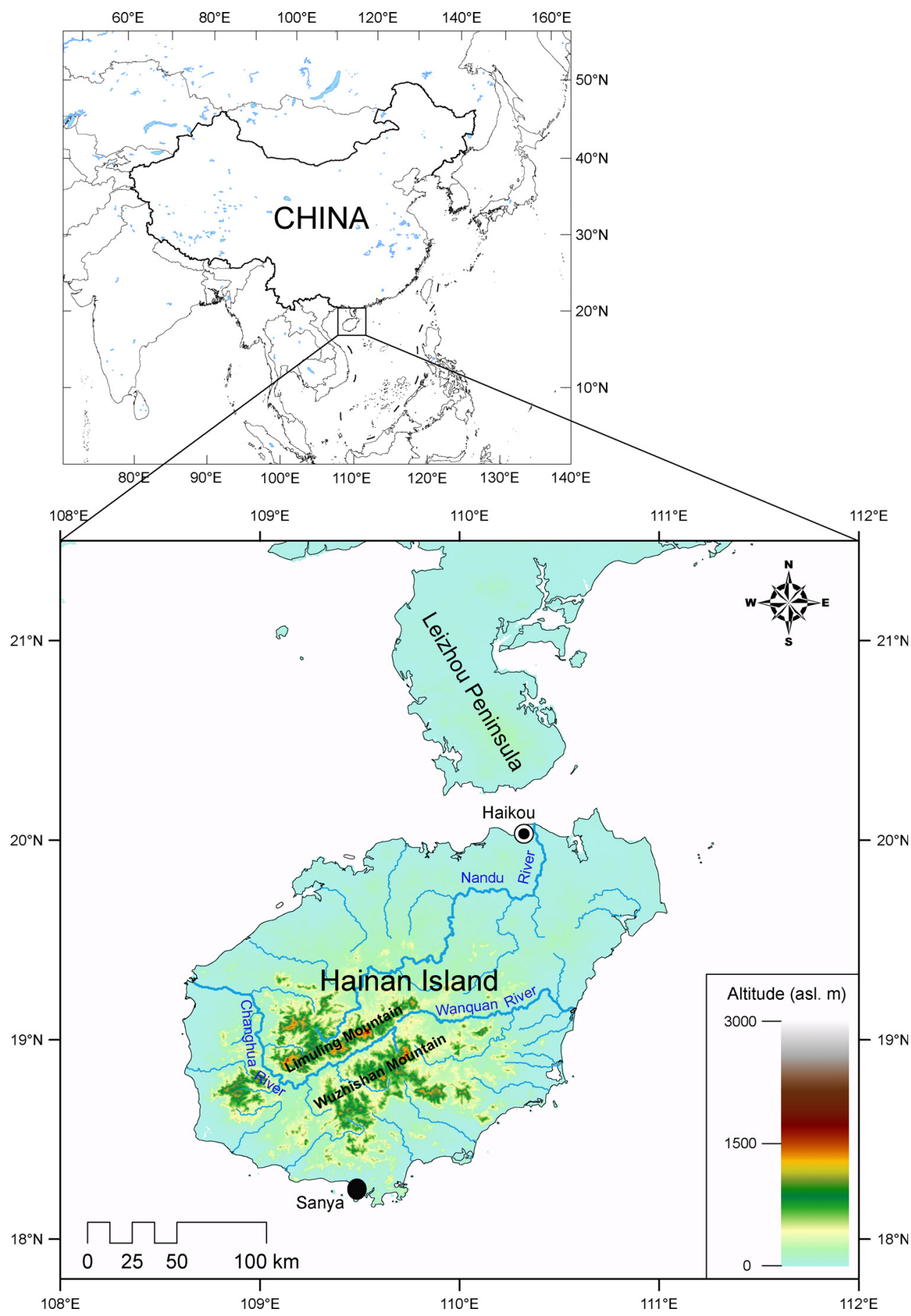

Fig. 1. The location and main water resources in Hainan Island.

of 154 freshwater fish species (138 native and 16 non-native species), belonging to 10 orders, 31 families and 104 genera are found on Hainan Island. Of these 138 native freshwater fish species and subspecies - belonging to nine orders, 26 families and 90 genera (Tab. 1) -32 are endemic to China. Cyprinidae and Gobiidae are the most species-rich and endemic species-rich families, accounting for $47.9 \%$ and $14.8 \%$ of total native species and $53.1 \%$ and $18.8 \%$ of the total endemic species of Hainan Island, respectively. More specifically, one Balitoridae (Plesio- myzon baotingensis), one Cobitidae (Cobitis baishagensis), six Cyprinidae (Acrossocheilusi kedai, Barbodes semifasciolatus, Folifer hainanensis, Garra hainanensis, Opsariichthys hainanensis, and Squalidus minor), One Nemacheilidae (Traccatichthys zispi), and five Gobiidae (Ctenogobius punctatus, Rhinogobius changjiangensis, $R$. linshuiensis, $R$. nandujiangensis, $R$. wangchuangensis) are endemic to Hainan Island. These 14 endemic species are the most important wild species and are worthy to be protected. In summary, Hainan Island, 
W. Xiong et al.: Knowl. Manag. Aquat. Ecosyst. 2018, 419, 6

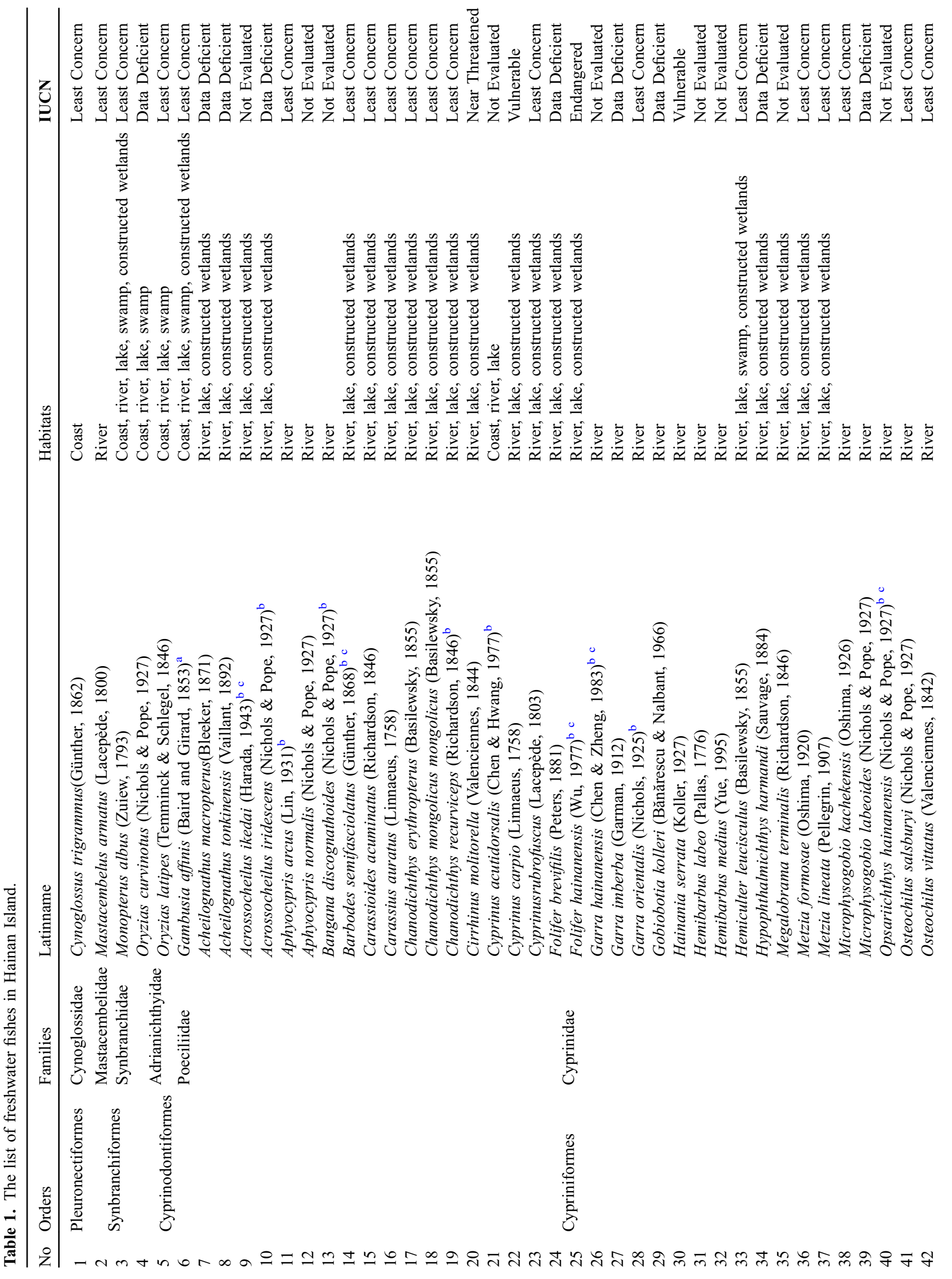




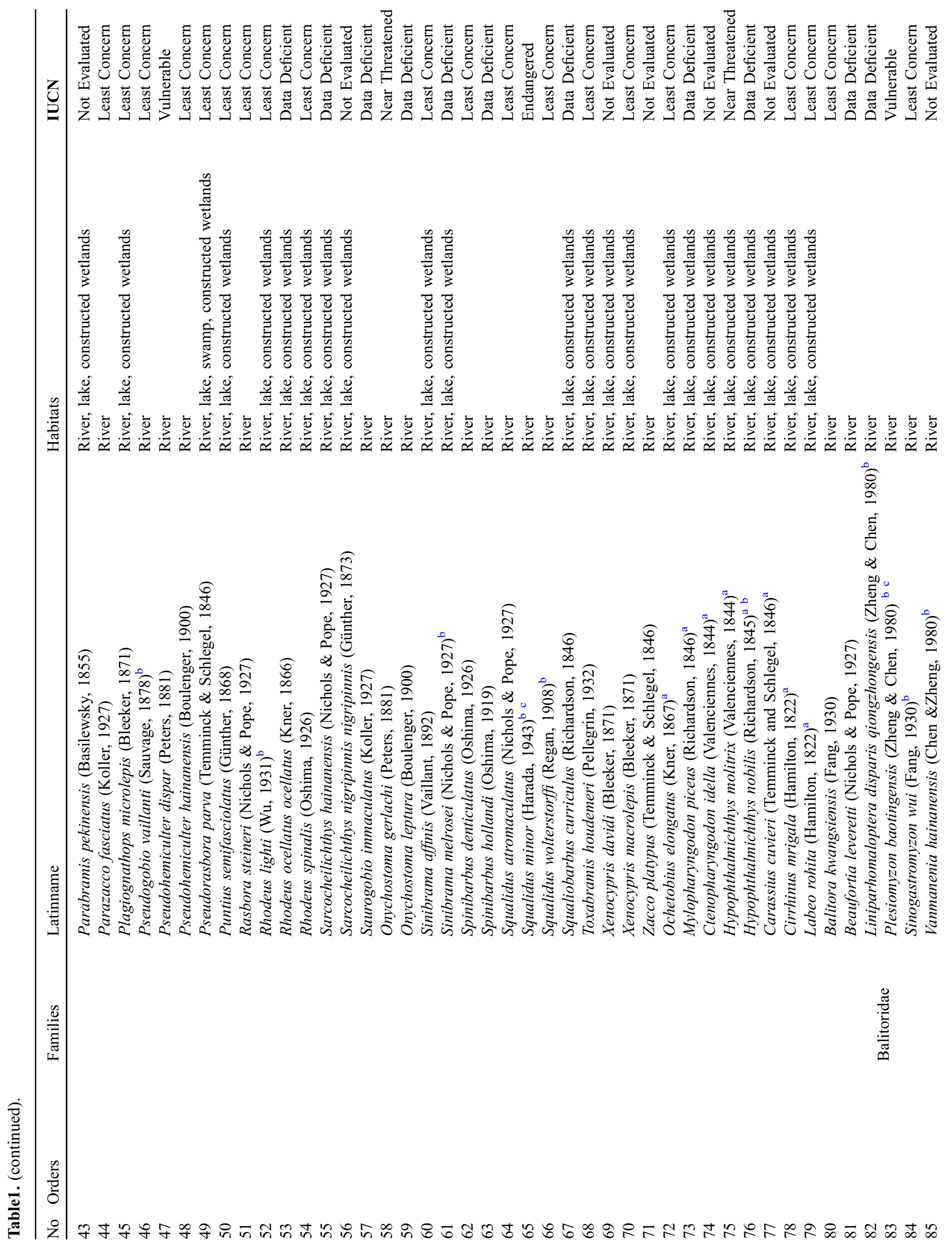




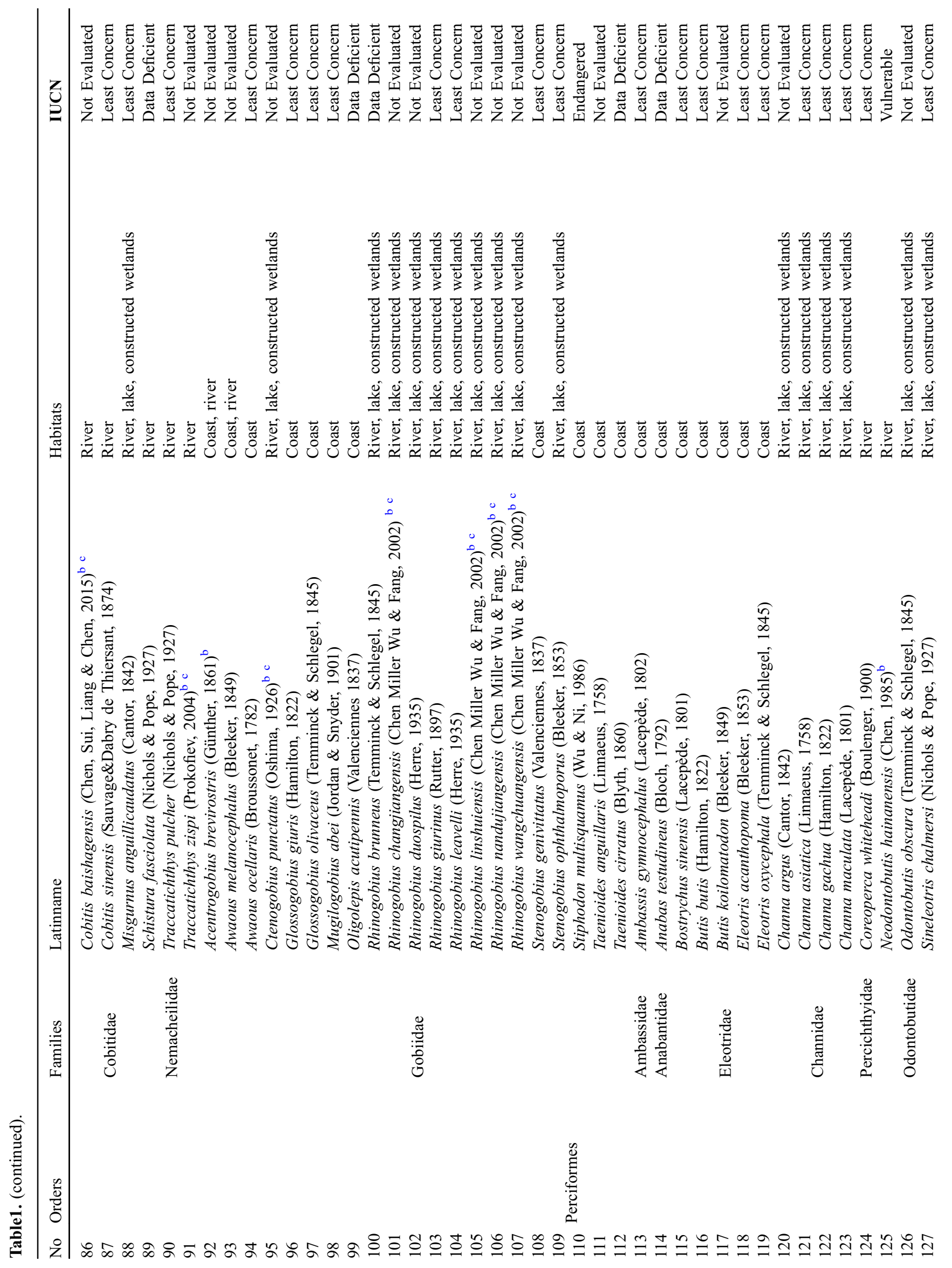


W. Xiong et al.: Knowl. Manag. Aquat. Ecosyst. 2018, 419, 6

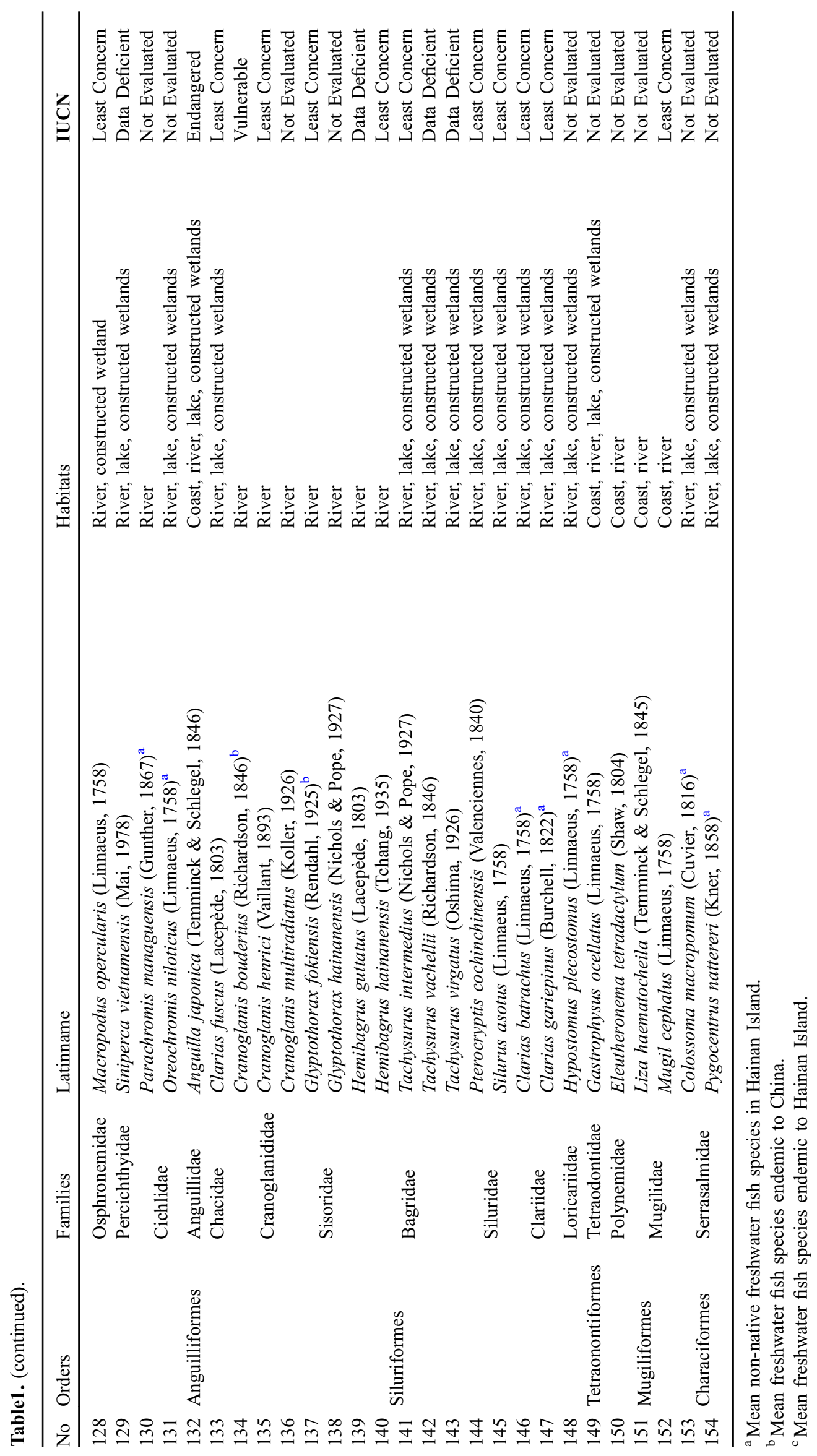


amounting for only $0.35 \%$ of total Chinese land area, contains 138 native freshwater fishes (about $10 \%$ of the Chinese total), with 38 species endemic to China and 14 species endemic to the island itself. Therefore, Hainan Island is very important for freshwater fish biodiversity conservation.

At the same time, there are 16 non-native freshwater fish species that occurred on Hainan Island (Tab. 1). Five freshwater fish species (Ochetobius elongates, M. piceus, Ctenopharyngodon idella, Hypophthalmichthys molitrix, and $H$. nobilis) were trans located from other regions of China and another 11 fish species were introduced from other countries or regions. Some non-native species, such as Nile tilapia (Oreochromis niloticus) and mosquito fish (Gambusia affinis) have widely established feral populations in Hainan Island.

Conservation statuses of the freshwater fish species of Hainan Island have been listed in Table 1. Of the 138 native freshwater fish species, about $10 \%$ (12 species) are categorized as threatened according to IUCN Red List Criteria. These threatened fish species mainly occur in the streams of Hainan Island (Wang and Xie, 2004).

\subsection{Habitats and fisheries}

According to the Chinese State Administration of Forestry, the total area of wetlands on Hainan Island is $32 \times 10^{4}$ ha, of which $75.63 \%\left(24.2 \times 10^{4}\right.$ ha $)$ are natural and $24.37 \%$ $\left(7.8 \times 10^{4}\right.$ ha) are manmade (Jiang, 2015).The wetlands of Hainan Island include five types: coastal (including shallow sea, sea grass bed, coral reef, rocky coast, shingle foreshore, mudflat beach, mangrove, estuary, delta, and lagoon), river (permanent river and flood plain), lake, swamp, and constructed wetlands (reservoir, pond, canal, aquaculture pond, salt pans).All information about area and rate of different types of wetlands are listed in Table 2.

Although coast wetland are the most abundant of five types of wetlands on Hainan Island, only 29 freshwater fish species, some Gobiidae (such as Awaous ocellaris, Glossogobius giuris, G. olivaceus etc.) and estuarine fish (such as Bostrychus sinensis, Butis butis etc), occurred in coastal wetland. Rivers only accounted for $12 \%$ of total Hainan Island wetlands surface area, however, almost all freshwater fish (137 species) were found to inhabit riverine habitats. The area of freshwater lakes is very small, accounting for only $0.17 \%$ of total Hainan Island wetlands, and rivers connected most lakes in Hainan Island, thus, except for some native fish (such as Mastacembelidae, Balitoridae, and Cobitidae) only living in the rivers in the mountains, most fish species ( 80 species) that occurred in rivers were also found in lakes. Swamp is the least abundant wetland type, accounting for only $0.01 \%$ of total wetland area and hosting only six small fish species. The area of constructed wetlands is increasing rapidly and these wetland areas host many native and non-native freshwater fish species (native species including Monopterus albus, Sinibrama affinis, and S. melrosei and non-native species including $C$. idella, $H$. molitrix, $H$. nobilis, and $O$. niloticus), which were introduced to reservoirs and aquaculture ponds to increase fisheries productivity. Most fish species (78 species) occurring in lakes also occurred in constructed wetlands. In general, riverine habitats host the greatest diversity of freshwater fish species on Hainan Island and most fish species could live in multiple habitats. All information about the habitats of the fish of Hainan Island is listed in Table 1.
Table 2. The trait of Hainan Island wetlands.

\begin{tabular}{llll}
\hline Class & Type & Area (hectare) & Rate (\%) \\
\hline & Shallow sea & 144695.05 & 45.21 \\
& Sea glass bed & 502.55 & 0.16 \\
& Coral reef & 5283.36 & 1.65 \\
& Rocky coast & 4355.27 & 1.36 \\
Coast & Shingle foreshore & 26405.51 & 8.25 \\
& Mudflat beach & 992.55 & 0.31 \\
& Mangrove & 4736.05 & 1.48 \\
& Estuary & 6969.28 & 2.18 \\
River & Delta & 22.82 & 0.01 \\
Lake & Lagoon & 7704.32 & 2.41 \\
Swamp & Permanent river & 35108.59 & 10.97 \\
& Flood plain & 4646.46 & 1.45 \\
& Freshwater lake & 556.91 & 0.17 \\
Constructed wetlands & Marshes & 43.68 & 0.01 \\
& Reservoirs & 56738.18 & 17.73 \\
& Aquals & 840.63 & 0.26 \\
& ponds & 15532.14 & 4.87 \\
& Salt pans & 4863.04 & 1.52 \\
\hline
\end{tabular}

The coast is important to local residents of Hainan Island for commercial and recreational fishing. Many fish species (such as Boleophthalmus pectinirostris, A. melanocephalus, etc) occurring in coastal areas are important delicacies for local residents (CCTV 2014),however it is noteworthy that some Gobiidae (such as Yongeichthys criniger, Acentrogobius caninus, etc) occurring here are poisonous to humans. Several people die every year because of Gobiidae poisoning. Hainan Island's rivers are also important recreational fishing site. Many native and non-native fish species (native species, including Aphyocypris arcus, A. normalis, Chanodichthys recurviceps and non-native species, including Carassius cuvieri, O. niloticus, Hypostomus plecostomus, Clarias batrachus and $C$. gariepinus) are caught by residents. The area of freshwater lakes and swamps is very small in Hainan Island, hence the commercial and recreational fishing in these two wetland-types are very limited, especially in swamps, where few people go fishing. On Hainan Island, constructed wetlands are the most important commercial fishing sites. Many fish species (M. piceus, C. idella, H. molitrix, H. nobilis, Cyprinus carpio, O. niloticus, C. auratus, Misgurnus anguillicaudatus, C. batrachus, C. gariepinus, Colossoma macropomum, Anguilla japonica, M. albus) were introduced into constructed wetlands (aquaculture ponds) for aquaculture (Xiong et al., 2015), especially since the 1990s, when Nile tilapia (O. niloticus) were introduced to Hainan Island for aquaculture (Wang et al., 2015).

\section{Threats to freshwater fish biodiversity}

Freshwater ecosystems possess high levels of biodiversity and endemism. They cover less than $1 \%$ of the earth's surface, yet support over $10 \%$ of the species (Strayer and Dudgeon, 2010) and are regarded to be in a state of crisis 


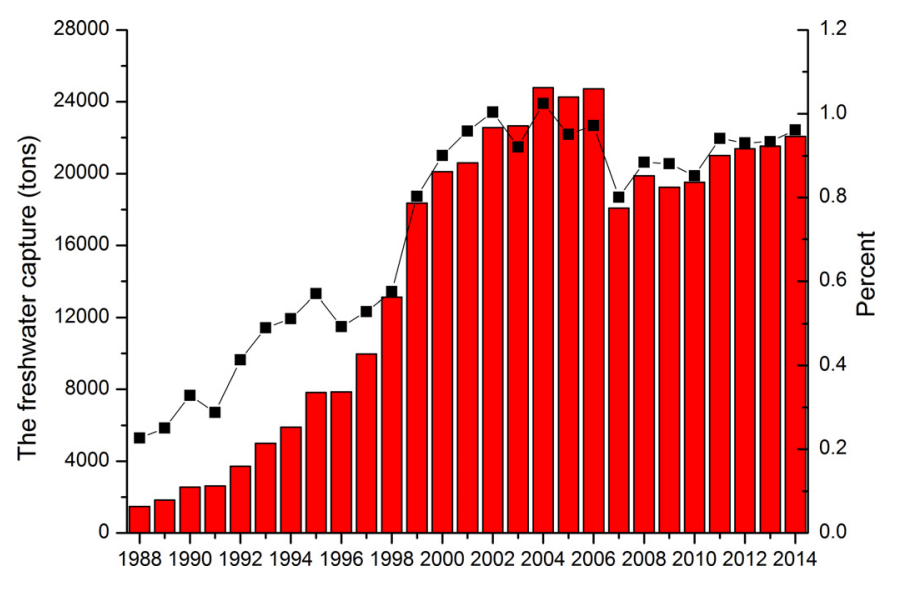

Fig. 2. The freshwater capture and percent of Hainan Island, red column mean production, black line mean rate.

(Vörösmarty et al., 2010), with higher proportion of species threatened with extinction here than in their terrestrial and marine counterparts (Strayer and Dudgeon, 2010).The main threats to freshwater biodiversity include: overexploitation, water pollution, flow modification, habitat degradation, and non-native species (Dudgeon et al., 2006).

Consistent with other regions of China, inland fisheries are an important threat to the freshwater fish of Hainan Island (Xing et al., 2016). In 2014, the freshwater fisheries of Hainan harvested 22073 tons, which is 15 times more than that of 26 years earlier. The freshwater fisheries accounting for $0.96 \%$ of the total freshwater fisheries harvest for the whole of China in 2014, which is four times greater than that of 26 years earlier (Fig. 2), Which shows that the exploitation pressure on freshwater fishes of Hainan Island has increased strikingly. Illegal fishing practices, such as electro fishing and poison fishing are widespread throughout Hainan Island and, despite strict penalties for perpetrators, remain pervasive and could cause dramatic declines in freshwater biodiversity (Zhao et al., 2015)

In the past twenty years, water pollution has increased rapidly in China, along with rapid economic development (Qin et al., 2013). Now, many rivers and reservoirs have been polluted by agriculture, industry, and rapid urbanization in Hainan Island (Zhao, 2015). Although the total industrial wastewater discharge has decreased by approximately $40 \%$ since twenty years ago (Zhang et al., 2013), some rivers and reservoirs have been polluted by nonpoint sources of contaminants. Meanwhile, the number of fish species has decreased, caused by water quality degradation by nonpoint source pollution (Harding et al., 1998) and lethal fish spill events, frequently occurring in some rivers of Hainan Island (CCTV, 2016).

Flow modification is one of the most critical threats to Chinese freshwater fish biodiversity (Fu et al., 2003; Axing et al., 2016). The spatial and temporal distribution of rainfall in Hainan Island is very uneven, with more than $80 \%$ of total rainfall between May and October. For more efficient and dependable water supplies, many hydrological infrastructures projects were undertaken between 1950 and 1980 in order to satisfy agricultural and hydropower demands. Today, over 2000 reservoirs are distributed all over Hainan Island
(Pearl River Fisheries Research Institute, 1989).However, nearly $20 \%$ freshwater fish species (26 species) are migratory species in Hainan Island. The loss of river connectivity due to the construction of reservoirs inevitably leads to the decline of some migratory species populations (e.g. A. japonica). Meanwhile, the construction of reservoirs altered fast flowing streams to slow flows, causing declines of fish dependent upon these fast flowing stream habitats (e.g. Glyptothorax fokiensis).

Over a period of seventy years the human population of Hainan Island increased from 2.59 million to over 9 million, in 2015 (Statistical Bureau of Hainan Province, 2016). Because of economic development and intensive human impacts, many natural habitats have been degraded and fragmented (Liao et al., 2009). A number of organisms (plants, amphibians, mammals and birds) have been threatened by habitat degradation on Hainan Island (Lei et al., 2003; Xie et al., 2007; Zhang et al., 2010; Meng et al., 2011). Research has shown that habitat degradation leads to loss of fish biodiversity in other regions (Kruk, 2007; Hermoso et al., 2011), however little is known about the actual negative impacts on native freshwater fish caused by habitat degradation on Hainan Island.

From the 1950s, many non-native fish were introduced to improve reservoir fisheries on Hainan Island, some of which, such as Nile tilapia (O. niloticus), are now abundant in a number of the reservoirs of Hainan Island. These non-native fish species play an important role for improving fisheries production and the economic development of Hainan Island. Based on the harvested quantities, tilapia, Black carp $(M$. piceus), Grass carp (C. idella), Silver carp (H. molitrix) and Bighead carp (H. nobilis) are the key non-native aquaculture fish groups in Hainan Island (Fig. 3a-d). The most dominant non-native aquaculture species are tilapia (Fig. 3d), which account for approximately $20 \%$ of the total harvest in China (unpublished data). Non-native freshwater species now constitute over $10 \%$ of the total freshwater fish species in Hainan Island (Tab. 1). These non-native fish species could lead to enormous negative impacts on native fisheries and biodiversity (Xiong et al., 2015). For example, the increase of Nile tilapia in the rivers of South China has led to declines in the CPUE from native fish communities as well as declines in the number of native fish species caught ( $\mathrm{Gu}$ et al., 2015). Another prominent example is the mosquito fish (G. affinis), which could pose a grave threat to Chinese freshwater biodiversity (Yan et al., 2009; Karraker et al., 2010). Inevitably, these non-native species could harm freshwater biodiversity in Hainan Island, but there is currently a dearth of quantitative impact studies in the literature and this shortfall should be addressed, as a priority.

\section{Conservation of freshwater fish biodiversity}

Freshwater fish are considered as the second most threatened animal group, after amphibians (Bruton, 1995), however, freshwater fish are the most important animal group for freshwater aquaculture in both China and World (Wang et al., 2015). Hence freshwater fish have conservation value, both for ecological and economic reasons. 

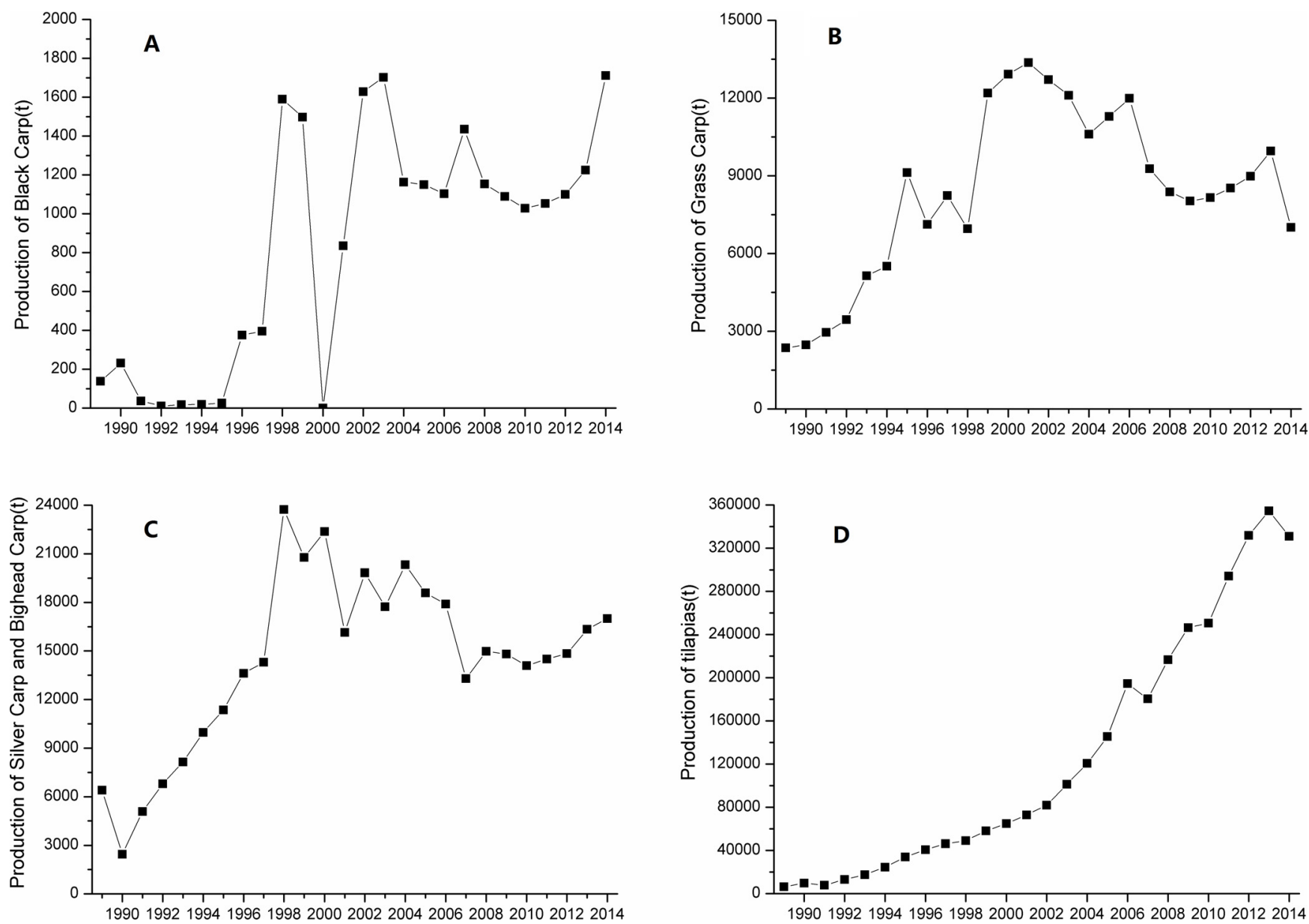

Fig. 3. Annual aquaculture production of main freshwater fish species in Hainan Island.

Establishment of conservation areas is considered a foundation of biodiversity protection (Chape et al., 2005; Naughton et al., 2005).To date, there have been 50 nature reserves established for the conservation of tropical forests, mangroves, coral reefs, birds and karst cave ecosystems in Hainan Island, however there are no conservation areas for protection of freshwater biodiversity. Arguably, freshwater conservation areas and fish passages should be established on Hainan Island, particularly around mountain streams which provide habitat for threatened and endemic fish species, such as $P$. baotingensis, $S$. minor and P. baotingensis.

Illegal fishing remains pervasive on Hainan Island and efforts should be focused on enforcing the law, to prevent the perpetuation of such practices electrofishing, poison fishing, and some kinds of trap fishing are strictly prohibited according to Chinese Fisheries Law. The use of gillnets with greater than $5 \mathrm{~cm}$ mesh should also be enforced (Chen and Chen, 2010), as gillnets with smaller meshes-sizes are commonly used on Hainan Island. Some rare and endangered fishes should be artificially propagated and released. In 2010, the artificially propagated and released freshwater fishes reached 16 billion in China, a three-fold increase from ten years prior (Ministry of Agriculture, 2015). Although data on the precise number of freshwater fish artificially propagated and released in Hainan Island is lacking, most artificial propagation and release efforts occurred in the Yangtze River and Pearl River. Currently, most artificially propagated and released species (like $C$. auratus, $C$. carpio, Misgurnus anguillicaudatus, M. albus, Parabramis pekinensis, Tachysurus vachellii) are used for fishery and aquaculture purposes. The key biological characteristics of many endemic and threatened fish species (e.g. Cranoglanis bouderius, Neodontobutis hainanensis, P. baotingensis) are still unknown, thus more studies should pay attention to life history traits and habitat requirements of the endemic and threatened fishes on Hainan Island.

The establishment of dams can lead to degradation of river habitat and impair the functionality of ecosystems (Dudgeon, 2000; Dudgeon et al., 2006), especially for anadromous fish species (Xie, 2003). However, the density of dams in Hainan Island is higher than in other regions of China and other countries. A number of mitigation approaches (including flow release of dams, establishing passage of migratory fishes, etc.) should be implemented, to minimize negative impacts. Meanwhile, habitat restoration (especially aquatic plant restoration) should be considered, to provide diverse habitat for native freshwater fish (Collingsworth and Kohler, 2010). Although there is very high diversity of aquatic plants on the island (Wang et al., 2008), intensive human activities could lead to decline and even extinction of aquatic plants, as in the rest of China. Thus, local government, citizens, and environmental organizations should pay more attention to the impacts of dams and carry out habitat restoration where necessary. 
China is currently the most seriously threatened county by invasion of aquatic organisms (Xiong et al., 2015; Wang et al., 2016; Xiong et al., 2017). Although little is known about the negative impacts of these non-native freshwater fishes in Hainan Island, these non-native fish species have caused great negative impacts in other regions of world (Pimentel et al., 2000; Ribeiro and Leunda, 2012). Non-native freshwater fish could lead to declines of native endemic species by hybridization, competition for food and habitat, predation, and habitat and ecosystem alterations (Xiong et al., 2015). Therefore, more research is needed on ecological and economic impacts of these non-native freshwater fishes in Hainan Island.

\section{Conclusion}

Based on the current study, Hainan Island contains a very high diversity of freshwater fish. At present, some factors (e.g. overexploitation, water pollution, flow modification, habitat degradation, and non-native species) have caused great negative impacts on native freshwater fishes. Therefore, effective protection and conservation of Hainan Island freshwater fish should be considered, including establishment of conservation areas, control of illegal fishing, development of sustainable fisheries, restoration of habitat, and the prevention of further non-native species introductions.

Acknowledgements. The authors are very thankful to Chunlong Liu for his assistance and useful suggestions. Special thanks to two anonymous reviewers whose comments greatly improved the manuscript. This research was supported by CAS-SEABRI (Y4ZK111B01).

\section{References}

Abell R. 2002. Conservation biology for the biodiversity crisis: a freshwater follow-up. Conserv Biol 16: 1435-1437.

Bruton MN. 1995. Have fishes had their chips? The dilemma of threatened fishes. Environ Boil Fish 43: 1-27

CCTV (China Central Television). 2014. A Bite of China II. Available at: http://shejian2.cntv.cn/.

CCTV (China Central Television). 2016. Hainan Haikou: a large number dead fishes occurred in Meishe River. Available at: http:// tv.cntv.cn/video/C10616/5314d4fa65e04e2589728081bad2a161.

Chape S, Harrison J, Spalding M, Lysenko I. 2005. Measuring the extent and effectiveness of protected areas as an indicator for meeting global biodiversity targets. Philos T Roy Soc B 360: $443-$ 455.

Chen YH. 2008. Avian biogeography and conservation on Hainan Island, China. Zool Sci 25: 59-67.

Chen YH. 2009. Distribution pattern and faunal characteristic of mammals on Hainan Island of China. Folia Zool 58: 372-384.

Chen Y, Chen YF. 2010. Investigation and protection strategies of fishes of Lhasa River. Acta Hydrobiol Sin 34: 278-285. (in Chinese)

Collingsworth PD, Kohler CC. 2010. Abundance and habitat use of juvenile sunfish among different macrophyte stands. Lake Reserv Manag 26: 35-42.

Dudgeon D. 2000. The ecology of tropical Asian rivers and streams in relation to biodiversity conservation. Annu Rev Ecol Syst 31: 239-263.
Dudgeon D, Arthington AH, Gessner MO, Kawabata ZI, Knowler DJ, Leveque C, Naiman RJ, Prieur-Richard AH, Soto D, Stiassny MLJ, Sullivan CA. 2006. Freshwater biodiversity: importance, threats, status and conservation challenges. Biol Rev 81: 163-182.

Fu C, Wu J, Chen J, Wu Q, Lei G. 2003. Freshwater fish biodiversity in the Yangtze River basin of China: patterns, threats and conservation. Biodivers Conserv 12: 1649-1685.

Gleick PH. 2003. Global freshwater resources: soft path solutions for the 21st century. Science 302: 1524-1528.

Gu DE, Ma GM, Zhu YJ, Xu M, Luo D, Li YY, Wei H, Mu XD, Luo $\mathrm{JR}, \mathrm{Hu}$ YC. 2015. The impacts of invasive Nile tilapia (Oreochromis niloticus) on the fisheries in the main rivers of Guangdong Province, China. Biochem Syst Ecol 59: 1-7.

Harding JS, Benfield EF, Bolstad PV, Helfman GS, Jones EBD. 1998. Stream biodiversity: the ghost of land use past. P Nat Acad Sci USA 95: 14843-14847.

Hermoso V, Clavero M, Blanco-Garrido F, Prenda J. 2011. Invasive species and habitat degradation in Iberian streams: an analysis of their role in freshwater fish diversity loss. Ecol Appl 21: 175-188.

Jiang HS. 2015. China wetlands resources Hainan volume. Beijing: China Forestry Publishing House.

Kang B, He DM, Perrett L, Wang HY, Hu WX, Deng WD, Wu YF. 2009. Fish and fisheries in the upper Mekong: current assessment of the fish community, threats and conservation. Rev Fish Biol Fish 19: 465-480.

Karraker NE, Arrigoni J, Dudgeon D. 2010. Effects of increased salinity and an introduced predator on lowland amphibians in southern China: species identify matters. Biol Conserv 143: 1079-1086.

Kruk A. 2007. Role of habitat degradation in determining fish distribution and abundance along the lowland warta river, Poland. $J$ Appl Ichthyol 23: 9-18.

Lei FM, Qu YH, Lu JL, LiuY, Yin ZH. 2003. Conservation on diversity and distribution patterns of endemic birds in China. Biodivers Conserv 12: 239-254.

Liao JW, Sun W, Yin QJ. 2009. Land use change and driving factors in west coastal area of Hainan Island since 1930s. J Subtrop Resour Environ 4: 17-23. (in Chinese)

Meng JH, Lu YC, Lei XD, Liu G. 2011. Structure and floristics of tropical forests and their implications for restoration of degraded forests of China's Hainan Island. Trop Ecol 52: 177-191.

Ministry of Agriculture. 2015. Report on the stat of the fishery ecoenvironment in China. Beijing. (in Chinese)

Myers N, Mittermeier RA, Mittermeier CG, Da Fonseca GAB, Pacala SW, Levin SA. 2000. Biodiversity hotspots for conservation priorities. Nature 403: 853-858.

Naughton TL, Holland MB, Brandon K. 2005. The role of protected areas in conserving biodiversity and sustaining local livelihoods. Annu Rev Envrion Resour 30: 219-252.

Olden JD, Kennard MJ, Leprieur F, Tedesco PA, Winemiller KO, García-Berthou E. 2010. Conservation biogeography of freshwater fishes: recent progress and future challenges. Divers Distrib 16: 496-513.

Pearl River Fisheries Research Institute. 1989. The freshwater and estuaries fishes of Hainan Island. Guangzhou: Guangdong Science and Technology Press (in Chinese).

Pimentel D, Lach L, Zuniga R, Morrison D. 2000. Environmental and economic costs of non indigenous species in the United States. Bioscience 50: 53-65.

Qin BQ, Gao G, Zhu GW, Zhang YL, Song YZ, Tang XM, Xu H, Deng JM. 2013. Lake eutrophication and its ecosystem response. Chinese Sci Bull 58: 961-970.

Ribeiro F, Leunda PM. 2012. Non-native fish impacts on Mediterranean freshwater ecosystems: current knowledge and research needs. Fish Manag Ecol 19: 142-156. 
Ricciardi A, Rasmussen JB. 1999. Extinction rates of North American freshwater fauna. Conserv Biol 13: 1220-1222.

Sodhi NS, Koh LP, Brook BW, Ng PKL. 2001. Southeast Asian biodiversity: an impending disaster. Trends Ecol Evol 19: 654-660.

Statistical Bureau of Hainan Province. 2016. Statistical yearbook of Hainan province. Haikou. (in Chinese)

Strayer DL, Dudgeon D. 2010. Freshwater biodiversity conservation: recent progress and future challenges. JN Am Benthol Soc 29: 344358.

Vörösmarty CJ, McIntyre PB, Gessner MO, Dudgeon D, Prusevich A, Green P, Glidden S, Bunn SE, Sullivan CA, Liermann CR, Davies P. 2010. Global threats to human water security and river biodiversity. Nature 467: 555-561.

Wang S, Xie Y. 2004. China species red list. Beijing: Higher Education. (in Chinese)

Wang Q, Yu D, LiZQ, Wang LG. 2008. The effect of typhoons on the diversity and distribution pattern of aquatic plants on Hainan Island, South China. Biotropica 40: 692-699.

Wang QD, Cheng L, Liu JS, Li ZJ, Xie SQ, De Silva SS. 2015. Freshwater aquaculture in PR China: trends and prospects. Rev Aquacult 7: 283-302.

Wang H, Wang Q, Bowler PA, Xiong W. 2016. Invasive aquatic plants in China. Aquat Invasions 11: 1-9.

Xie P. 2003. Three Gorges dam: risk to ancient fish. Science 302: 1149.

Xie F, Lau MWN, Stuart SN, Chanson JS, Cox NA, Fischman DL. 2007. Conservation needs of amphibians in China: a review. Sci China Ser C 50: 265-276.

Xing YC, Zhang CG, Fan EY, Zhao YH. 2016. Freshwater fishes of China: species richness, endemism, threatened species and conservation. Divers Distrib 22: 358-370.
Xiong W, Sui XY, Liang SH, Chen YF. 2015. Non-native freshwater fish species in China. Rev Fish Biol Fish 25: 651-687.

Xiong W, Shen CY, Wu ZX, Lu HS, Yan YR. 2017. A brief overview of known introductions of non-native marine and coastal species into China. Aquat Invasion 12: 109-115.

Yan YZ, Chen YF, Tao J. 2009. Ecological invasion of Gambusia affinis: a review. Chin J Ecol 28: 950-958.

Yap SY. 2002. On the distributional patterns of Southeast-East Asian freshwater fish and their history. J Biogeogr 29: 1187-1199.

Zakaria-Ismail M. 1994. Zoogeography and biodiversity of the freshwater fishes of Southeast Asia. Hydrobiologia 285: 41-48.

Zeng ZX, Zeng XZ. 1989. Nature geography of Hainan Island. Beijing: Science Press. (in Chinese)

Zhang HD. 2001. The diversity of the Hainan flora. Ecol Sci 20: 1-10. (in Chinese)

Zhang MX, Fellowes JR, Jiang XL, Wang W, Chan BPL, Ren GP, Zhu JG. 2010. Degradation of tropical forest in Hainan, China, 1991-2008: conservation implications for Hainan Gibbon (Nomascus hainanus). Biol Conserv 143: 1397-1404.

Zhang J, Wang DR, Jennerjahn T, Dsikowitzky L. 2013. Land-sea interactions at the east coast of Hainan Island, South China Sea: a synthesis. Cont Shelf Res 57: 132-142.

Zhao DB. 2015. Distribution, enrichment and sources of heavy metals in surface sediments of Hainan Island rivers, China. Environ Earth Sci 74: 5097-5110.

Zhao YH, Gozlan RE, Zhang C. Current state of freshwater fisheries in China. In: Craig JF, ed. Freshwater fisheries ecology. Hoboken, New Jersey: John Wiley \& Sons Ltd, 2015, pp 221229.

Zou FS, Song XJ, Jiang HS, Chen K. 1999. Types and characteristics of the wetland of Hainan Island. Trop Geogr 19: 204-207.

Cite this article as: Xiong W, Wang Q, Xie D, Fletcher DH, He D. 2018. Factors influencing tropical Island freshwater fishes: species, status, threats and conservation in Hainan Island. Knowl. Manag. Aquat. Ecosyst., 4196. 